\title{
On the Birthday of N.V. Sennikov
}

DOI: $10.1134 / \mathrm{S} 0031030110010181$

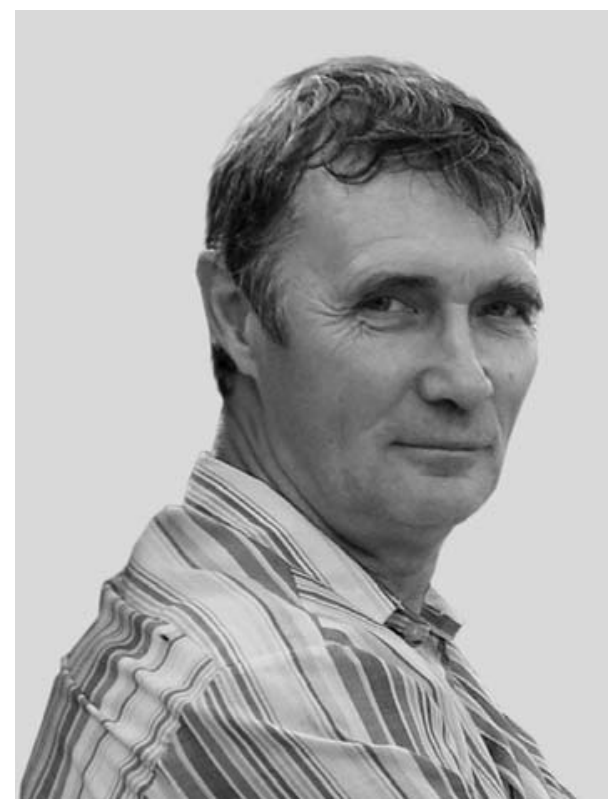

August 22, 2009 was the 60th birthday of the wellknown scientist Professor Nikolai Valerianovich Sennikov, an expert on Paleozoic biochronology, paleontology, stratigraphy, and paleogeography, and Dr. Sci. in geology and mineralogy.

In 1971, after graduation from the GeologicalGeophysical Faculty of Novosibirsk State University, Nikolai Valerianovich Sennikov received a PhD scholarship at the Institute of Geology and Geophysics of the Siberian Branch of the Academy of Sciences of the USSR, in the laboratory of Paleozoic Paleontology and Stratigraphy, where he developed from a junior researcher to senior researcher and leading researcher. In 1994, he was awarded a Dr. Sci. degree, from 1996 worked as a Deputy Director (Scientific Research) at the Institute of Oil and Gas Geology of the Siberian Branch of the Russian Academy of Sciences, and from 2005 of the Trofimuk Institute of Petroleum Geology and Geophysics of the Siberian Branch of the Russian Academy of Sciences.

His main research interests are focused on the history of Siberian and neighboring Paleozoic oceanic and shelf sedimentary and volcanic-sedimentary basins. He has made a distinctive profile in biostratigraphy, and has a broad knowledge and strategic approach. Nikolai Valerianovich is a specialist in the development and refinement of methods of paleogeography, lithostratigraphy, and high-resolution zonal biostratigraphy. $\mathrm{He}$ conducts detailed stratigraphic subdivision of sedimentary rocks using biochronology based on fossilized pelagic organisms, including graptolites, conodonts, chitinozoans, and radiolarians. For further refinement of the Ordovician-Silurian-Lower Devonian chronostratigraphy, Nikolai Valerianovich proposed parallel zonal scales based on graptolites, conodonts, and chitinozoans for all major regions of Siberia, from the Middle Cambrian to the Lower Devonian. The scope of his scientific research goes far beyond the borders of the Siberian regions. The summaries of the material from Siberia allowed him to conduct a number of studies in event-based lithostratigraphy, biostratigraphy, and paleontology of the Ordovician of the East European Platform, the Silurian of the Chukchi Peninsula, the Ordovician, Silurian, and Lower Devonian of Uzbekistan, Tajikistan, and Kyrgyzstan. The scientific results of Nikolai Valerianovich are widely used in regional geology, geodynamics, and refinement of Paleozoic geochronology. His field team includes geologists from other institutes and surveys, and also from geological institutions abroad.

Nikolai Valerianovich is the author and co-author of more than 280 scientific papers (over 40 of which are published outside Russia), including 15 monographs (two of which are single-authored). He has presented his scientific results in Great Britain, Czech Republic, Poland, Spain, Japan, China, and Argentina. Nikolai Valerianovich is a Corresponding Member of the Silurian Subcommission of the International Stratigraphic Commission, a deputy Chairman of the Siberian Regional Interdepartmental Stratigraphic Commission, a member of the Ordovician-Silurian Commission of the Russian Interdepartmental Stratigraphic Committee.

Nikolai Valerianovich is very much involved in teaching and supervising students. He has lectured for many years at Novosibirsk State University, where he is a deputy Chairman of the Dissertation Council (for Dr. Sci. and $\mathrm{PhD}$ degrees) in Paleontology and Stratigraphy. $\mathrm{He}$ is a member of the editorial boards of the journals "Geologia i geofizika" (Geology and Geophysics) and its supplement "Novosti paleontologii i stratigrafii" (News in Paleontology and Stratigraphy), and of "Xinjiang Petroleum Geology" (China, Urümqi-Karamay).

Colleagues, friends, and students of Nikolai Valerianovich heartily congratulate him on his birthday and wish him inexhaustible energy, new ideas, creative longevity, good Siberian health, and good luck!

Friends and colleagues 